\title{
Institutionalization in the Politics of China's Disaster Management
}

\author{
CHEN GANG
}

\begin{abstract}
In the study of institutionalization in authoritarian regimes, non-repressive institutional pillars in non-democratic governance are often neglected. Through the research on the People's Republic of China's two rounds of reinstitutionalization in natural disaster management, a life or death issue for all Chinese dynastic regimes, this article aims to make contributions to new institutionalist studies of authoritarianism that help to explain the Chinese Communist Party's 'authoritarian resilience'. Based on analysis of the evolution of China's thematic disaster response plans and disaster management mechanisms in the reform period, the article discusses different institutional imperatives or fundamental challenges the authoritarian institutional designers needed to address before and after the 2008 Sichuan earthquakeand to what extent the institutionalization and reinstitutionalization have been effective in addressing these challenges. ${ }^{1}$
\end{abstract}

Keywords: authoritarianism, citizen activism, disaster management, institutionalization, participation

\section{Introduction}

With its vast territory and diverse climatic and geological conditions, China is vulnerable to frequent natural disasters, which today affect about 300 million people every year. Since the Chinese Communist Party (CCP) seized power in 1949, the authoritarian Party-state has been trying to improve the effectiveness of disaster management by modernizing relevant bureaucratic organizations and establishing standardized norms and guidelines to direct such work, which is vital for the survival of the communist regime. Despite the importance the CCP has attached to disaster management, much of the early research on institutions in authoritarian regimes has neglected such non-repressive institutional pillars in the non-democratic governance of contemporary China, with the exception of a few studies (Chen 2012: 130-148; Lim 2011: 11-20; Tan, Hwang and Wang 2011; Yi et al. 2012: 295-309). The majority of these researchers has noticed a distinctive change in the bureaucratic struc- 
ture and norms concerning disaster management after the Tangshan earthquake in 1976, which happened the same year the Mao era ended. However, very little research has been done to follow closely the recent effort made by the party-state to reinstitute national disaster management in the hope of integrating the increasingly fragmented bureaucracy and reining in citizen activism in the age of the Internet and social media (Yang 2009). By improving the bureaucratic structure, accepting foreign aid and enhancing financial and technical preparation, the Chinese government has done fairly well in controlling annual disaster death tolls to under 10,000 in most years (Figure 1). However, new problems such as growing civic activism and supervision facilitated by online media as well

FIGURE 1: Annual death toll of natural disasters in China (2006-2012)

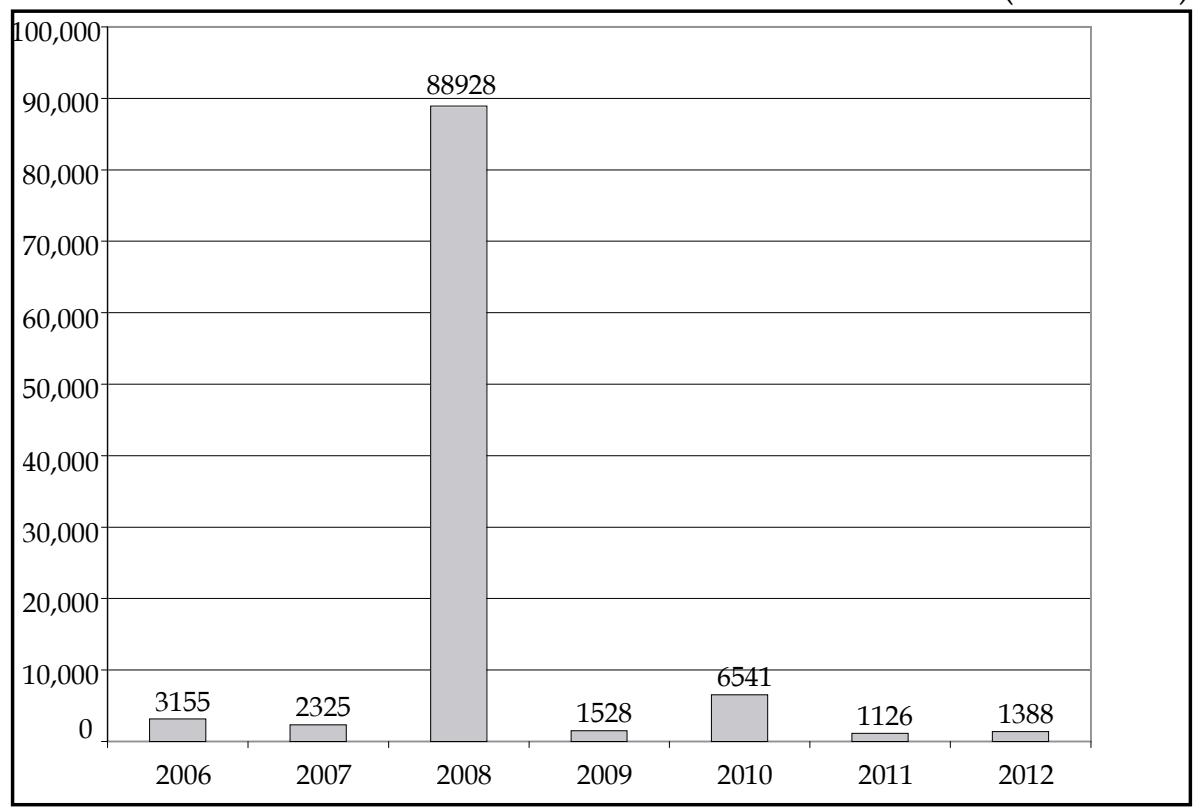

Source: Press Release from China's Ministry of Civil Affairs, 3 May 2013

as intra-regime tensions emerged during the rescue and reconstruction process following the 2008 Sichuan earthquake. In response to some of these challenges, the authoritarian government reorganized the disaster management system, writing a variety of new norms and guidelines in new national preplans and provisions. The reinstitution, albeit administratively efficient in coordinating various intra-bureaucracy players to achieve a better division of work, failed to address the urgent civic demand for substantial participation and supervision. The increasingly salient influence of the Internet and social media was overlooked by the institutional designers. Such neglect subsequently had an enormous 
negative impact on the credibility of the government-dominated disaster management system in the second Sichuan earthquake, in 2013.

The study of institutionalization in authoritarian regimes, which takes seriously previously neglected institutional pillars of non-democratic governance, was revived when new institutionalist studies of authoritarianism shifted their focus to institutions of representation and division of power that people tend to associate with liberal-democrat regimes (Schedler 2009). Traditional institutionalism focused on institutions of repression and manipulation that were distinctively authoritarian, such as the Party state and secret police. In contrast, new institutionalist research on authoritarianism is keen to look at institutions of representation and division of power, such as federalism and legalism, as well as discussing under what circumstances non-repressive sectors might be repressive. Current scholarship has touched upon many aspects of the CCP's reinstitutionalization endeavour for adaptation and co-optation purposes, which includes the professionalization of the civil service (Brødsgaard 2002), rebuilding of Party cells (Pieke 2009), experimenting with 'intra-party democracy' (Li 2009; Zheng 2012) and regular career cadre training in Party Schools (Shambaugh 2008). However, the Party-state's repackaging of disaster management institutions as well as its effectiveness in maintaining the CCP's 'authoritarian resilience' (Heilmann and Perry 2011; Nathan 2003: 6-17; Shambaugh 2012: 8-22; Wang and Tan 2013: 199) in the face of bureaucratic fragmentation and citizen activism is a field still to be ploughed. ${ }^{2}$ In the shadow of the Arab Spring that has toppled a string of entrenched dictatorships in North Africa, the CCP's central authority has been facing unprecedented challenges from societal forces and vested interests within the regime in the realm of disaster management. Its credibility and legitimacy have been overtly damaged by scandals involving the use of donations and shoddy construction projects. In Huntington's (1968) classic formulation, maintaining political order in changing societies requires maintaining a balance between the capacity of elite state institutions and the volume of mass political mobilization. There has been significant divergence among China specialists over the future of the CCP. Hence the study of the relationship between institutionalization and participation, which was argued by Winckler (1984: 483) as the most important domestic relationship in shaping the political transition of authoritarian regimes, in the realm of China's disaster management will shed light on the CCP's ability to co-opt citizen activism and adapt to an increasingly decentralized and fragmented bureaucratic landscape. 
In the first three decades after the start of reform, remarkable economic growth and the effective governance limiting the devastating impact of natural calamities have legitimized the CCP's rule and absorbed most citizens' contentious energies. From 1978 to 2008, the Party-state proved adept in adapting political institutions to absorb and selectively repress civic activism and intra-elite tensions. Nevertheless, a watershed came when the eventful year of 2008 witnessed the Sichuan earthquake, the Beijing Olympics, the global financial crisis and the burgeoning of social media. Based on analysis of the evolution of China's thematic disaster response plans and disaster management mechanisms in the reform period, this article discusses different institutional imperatives or fundamental challenges the authoritarian institutional designers needed to address before and after 2008 in disaster managementand to what extent the institutionalization or reinstitutionalization has been effective in addressing these challenges. The article tries to find clues on whether once-successful institutions built by the $\mathrm{CCP}$ in the contemporary authoritarian regime are still adept at containing mass demand for participation. A methodology employing the neo-institutionalist approach in accounting for the CCP's authoritarian resilience is adopted here, with the formal institutional evolution of China's natural disaster management system ${ }^{3}$ as a case in point to test the general applicability of the resilient authoritarianism perspective to China. Benefiting from a rich institutionalist literature in examining institutional complementarity among different agencies and between central and local governments (Hall and Soskice 2001), in separately accounting for efficiency, effectiveness and legitimacy of institutions (Krasner 1983; Greif 2006), or in accounting for institutional change (North 1990; Aoki 2001), the research intentionally selects the often-neglected yet important topic of natural disaster management to expand knowledge about the institutional pillars that support such resilience and also the limitation of institutional flexibility. The article is designed to enrich the authoritarian resilience theory that attributes CCP's resiliency mostly to remarkable economic achievement (Wang and Tan 2013), 'inner-party democracy' or social management (Wang and Huang 2013).

\section{Institutionalization of Natural Disaster Management in China}

In history, the Chinese people's fight against natural calamities has been never-ending, with major imperial regimes able to formalize systematic institutions to manage natural disasters. Historians have called such 
disaster and famine-relief governance in ancient China 'famine politics' (huangzheng) (Dong South-Song-Dynasty (1127-1279); Deng 1937; Meng 1999), which included policies, practices, institutions and even theories related to preparedness, relief and recovery in the disaster management cycle. Yet despite the intense attention paid to natural disasters, China's imperial dynasties failed to establish an independent department specialized in disaster management.

After the Republic of China (ROC) took power from the monarch of the Qing Dynasty and set up its government in 1912, modernized institutions managing natural disasters were introduced, with special departments appointed to take charge of relevant affairs. In August 1912, the Ministry of Internal Affairs (nei wu bu) was set up inside the ROC Beijing government to take charge of disaster relief work, philanthropy and public health, with its subordinate department of civil affairs taking over the detailed disaster alleviation work (Sun 2004: 55). In May 1921, the Ministry of Internal Affairs publicized a statute to institutionalize a national committee on disaster management, which aimed to find the causal factors behind natural disasters and work out corresponding preparation and prevention plans (Gong 1996: 500-504). During the ROC period, China was in the early stages of industrialization and modernization, which facilitated the introduction of modern-style bureaucracy to manage natural disasters. However, since the ROC's nation-building process was often disrupted by large-scale wars and severe political confrontation, the distracted bureaucracy failed to function properly to address major natural disasters.

After the CCP won a civil war and founded the People's Republic of China (PRC) in 1949, the new regime in its early days continued to authorize the Ministry of Internal Affairs (nei wu bu) to be responsible for disaster relief work. In February 1950, a central committee on disaster relief (zhongyang jiuzai weiyuanhui) was established to coordinate disaster management work among the various ministries (Internal Affairs, Finance, Agriculture, Water Resources and Health) and other related ministries and governmental departments. Vice Premier Dong Biwu was the head of the committee. Following the central government's edict, local governments subsequently set up their disaster relief committees at the prefecture, county and township levels. During the frenetic Great Leap Forward movement in 1958, the central committee on disaster relief and many of its local branches were abolished amidst people's blind faith that natural disasters would no longer pose a serious threat in the communistic China. In 1969, two years after the start of the Cultural 
Revolution (1966-1976), the Ministry of Internal Affairs was abolished and most of its disaster management functions were scattered among other ministries and departments, which led to inefficiency and even chaos in this area.

In the reform era, the PRC has gradually normalized the bureaucratic system in charge of natural disaster management once disrupted by the anarchical Cultural Revolution. In 1978, two years after the Cultural Revolution was over, the Ministry of Civil Affairs (min zheng bu) was re-established to resume some disaster management functions. During most of the 1980s, the Ministry of Civil Affairs was in charge of disaster relief only in rural areas, while the State Economic Commission (SEC) has the power to coordinate all the disaster management work at the national level. In 1988, when the SEC was abolished in another round of administrative reform, that responsibility was shifted to the State Planning Commission, which later transferred this function to the State Economic and Trade Commission established in 1993. In 1998, according to a circular issued by the State Council General Office, the State Economic and Trade Commission officially handed over the function of organizing and coordinating disaster relief work to the Ministry of Civil Affairs, ${ }^{4}$ which since then has institutionalized its pivotal role in managing natural disasters in China.

In 1989, in response to the United Nations resolution to designate the 1990s as the International Decade for Natural Disaster Reduction (IDNDR), the Chinese government founded the National Commission for the International Decade on Natural Disaster Reduction, which was comprised of more than 30 ministries and commissions, including the Ministry of Civil Affairs, the Foreign Ministry, the State Planning Commission and relevant military agencies and social groups. It soon became the top-level decision-making panel to command and coordinate disaster relief work scattered throughout different ministries and departments. In 2000, as soon as the IDNDR was over, it was renamed the China Commission for International Disaster Reduction, which turned out to be a regular interagency coordination body under the State Council rather than an interim organization in answer to the call from the United Nations. In January of 2005, it was renamed the China National Committee for Disaster Reduction (NCDR). Headed by a vice premier of the State Council, the NCDR is responsible for studying and formulating principles, policies and plans for disaster reduction, coordinating major disaster activities, giving guidance to local governments in their disaster reduction work and promoting international exchanges 
and cooperation. ${ }^{5}$ Since then, the Chinese government has formalized the NCDR as the top interagency mechanism in charge of disaster management, with the Ministry of Civil Affairs taking on routine jobs of the NCDR and playing a pivotal role in coordinating work done by various ministries and sectors.

According to the division of responsibilities under the current disaster management bureaucracy, the Ministry of Civil Affairs deals with most of the daily administrative work of the NCDR. It also coordinates disaster relief work among various departments, collects and releases the latest disaster situation information, manages and distributes the aid fund and materials from the central government, cooperates with other departments in relocating disaster-hit people, prepares the national level food and rescue material reservation, organizes public donations and undertakes international cooperation in this area. ${ }^{6}$ The Ministry of Finance formulates the yearly budget for national disaster relief, supervises the use of such funds and provides special funds for severe disasters. The State Administration of Taxation formulates and implements the tax waiver policy in disaster-hit regions. The Ministry of Agriculture is in charge of the provision of agricultural materials such as fertilizers and diesel in the disaster-hit regions and helps peasants produce grains in the recovery phase. The Ministry of Water Resources plays a vital role in fighting major floods and droughts and thus undertakes the administrative work of the State Flood Control and Drought Relief Headquarters, another interagency mechanism to cope with severe floods and droughts. The Ministry of Health is in charge of medical services in disaster-hit regions, while the Ministry of Transport repairs the roads and railways damaged in natural disasters. The China Earthquake Administration forecasts and monitors earthquakes, while the China Meteorological Administration takes charge of weather forecasts and releases warnings on meteorological disasters. Meanwhile, the Chinese government has established ad hoc leading panels on combating floods and droughts and earthquake relief.

During the reform period, in which the PRC has been paying more attention to the institutionalization and legalization of government activities, the country has enacted more than 30 laws and regulations related to disaster management. These include the PRC Flood Control Law, the Law on Earthquake Preparedness and Disaster Reduction, the Emergency Response Law, the Regulation on Forest Fire Control and the Regulation on the Participation of Armed Forces in Emergency and Disaster Rescue Actions. The Chinese government has enacted de- 
tailed regulations on comprehensive disaster relief work, the reporting and monitoring of disaster situations, the management and use of aid materials and funds as well as on receiving international and domestic donations. Under the related laws and regulations, the Chinese government has institutionalized an emergency response system comprising the National Master Plan for Responding to Public Emergencies, five national thematic disaster response plans and emergency response plans for 15 central government departments and their detailed implementation plans and operation norms (United Nations Economic and Social Council 2008: 9). Compared to the PRC's early experiences in disaster management, the bureaucratic system in the reform period, facilitated by all these laws, regulations and plans, has clarified the assignment of duties among major departments. It has also standardized the procedures through which the government, the armed forces, businesses and civil society plan for and reduce the impact of disasters, react during and immediately following a disasterand take steps to recover after the disaster.

\section{Evaluation of Institutionalization in Disaster Management: Norms and Operational Mode}

The Party-state's normalization and institutionalization of the bureaucratic system overseeing natural disaster management have profound political implications in coordinating intractable central-local relations (Zheng 2007) and improving the regime's international image and legitimacy. Since local governments in China had no power to raise revenue and most of their expenditures were disbursed by the central government in a strict top-down system prior to 1980, the central government had to be responsible for allocating relief funds to localities where natural disasters had occurred. In the 1980s and early 1990s, local governments gradually assumed control of their own revenue and expenditure under a contractual fiscal system characterized by defining a fixed sum paid to or received from the central government (Lin 2000: 477-490; Loo and Chow 2006: 215-216). Nevertheless, most disaster relief funds still came from the central government. From 1983 to 1994, 85 per cent of the disaster relief funds used in Anhui Province were allocated by the central government, while only about 15 per cent came from the provincial and county-level governments (Sun 2004: 192). In 1994, China introduced the Tax Sharing System allowing local governments to share tax revenues with the central 
government (Chung 1995: 2-3; Loo and Chow 2006: 216). Thereafter, local governments at all levels also started to disburse more for disaster management. Local governments today shoulder about 30 per cent of China's total fiscal expenditure on disaster management, which is much higher than in the pre-1994 period. Yet they are still being pressured to pay more for disaster relief to ease the fiscal burden upon the central government.

Shifting from its insular attitudes towards foreign aid for disaster relief during the Cold War, China has been readily receiving international donations through different channels in the reform period. In the early 1980s, the reformist leadership decided to accept foreign aid and opened its disaster relief system to the outside, with the United Nations as its major institutional channel to engage the world. The year 1989 was a turning point, when China joined the International Decade for Natural Disaster Reduction (IDNDR) initiated by the UNand set up the National Commission for the IDNDR, which later became the top-level decision-making panel on national disaster relief work. As the predecessor of the National Committee for Disaster Reduction, the National Commission for the IDNDR in the 1990s had learnt a lot of modernized norms and practices in the field of disaster management through international exchanges and activities. The Ministry of Civil Affairs, the Ministry of Foreign Affairs, as well as the governmentorganized Red Cross Society of China and China Charity Federation are now the major sectors involved in receiving overseas aid and donations. In natural calamities like the 2008 Sichuan earthquake that have claimed huge casualties and economic losses, the Chinese government not only accepted international aid and donations, but also welcomed rescue and medical teams from foreign countries to the disaster-hit regions.

Before the reform period, the PRC government had regarded the death tolls in natural disasters as state secrets and refused to release them to the public. Foreign media were not allowed to cover the disaster relief work on the spot at that time. As a move to greater transparency, in 2005 China announced it would no longer treat the death toll in natural disasters as a state secret. The National Administration of State Secrets declared the declassification of disaster-related death tolls at almost the same time. ${ }^{7}$ During the Sichuan earthquake in 2008, the country's worst natural disaster in the reform period, official media provided round-theclock coverage of the earthquake and the rescue efforts, demonstrating remarkable openness. 
In sharp contrast to the opaque and seclusive disaster relief work in the Maoist era, China's gradual openness to international aid and media coverage has won international praise from organizations like the United Nations (United Nations Economic and Social Council 2008) as well as domestic supportand thus consolidated the authoritarian regime's legitimacy that had been severely damaged by the Cultural Revolution and Tiananmen (June 4th) crackdown.

As in many other parts of the world, China today has been making disaster mitigation and preparedness a priority task at policy, institutional and operational levels. By accepting well-established international norms to guide the country's disaster relief work, the Chinese government has managed to keep the casualties caused by natural disasters at relatively low levels. In the disaster management cycle, pre-disaster mitigation and preparedness activities not only reduce the probability that a disaster will occur and the negative effects of unavoidable disasters, but also produce greater efficiency in responding to any emergency. Therefore, compared with the post-disaster phases of response and recovery, the preventive and preparation measures are more cost-effective and thus deserve intensive policy attention.

Among all the preventative measures, building up flood control facilities and related warning/forecasting systems has drawn the most attention from the Chinese government, especially since the Yangtze River floods in 1998, the heaviest in the reform period, led to a series of collapsed levees and killed more than 4,150 people. In the early stage of the reform period, the state followed a blatantly urban-biased development strategy with most resources diverted to glamorous industrial and urban projects instead of water conservancy and forestation projects. As a result, China has to bear with the inestimable environmental costs of soil erosion and deforestation that exacerbated the floods (Figure 2 shows that areas affected by floods had been on the rise from 1978 to 1998). Since 1998, however, substantial funds have been generated from both central and local governments for the reinforcement of the levees and for building flood storage and detention basins. China has invested heavily in the world's largest flood control project, the Three Gorges dam completed in 2006. The government has also set up nationwide early-warning networks to monitor and identify risks and threats of meteorological, oceanic, geological, earthquake and forest fire disasters. Influenced by the government's enhanced pre-disaster prevention thereafter and favourable climate conditions, from 1998 to 2008, the total area affected by floods in China was greatly reduced (Figure 2). Since 
FIGURE 2: Areas Affected by Floods in China (1,000 hectares)

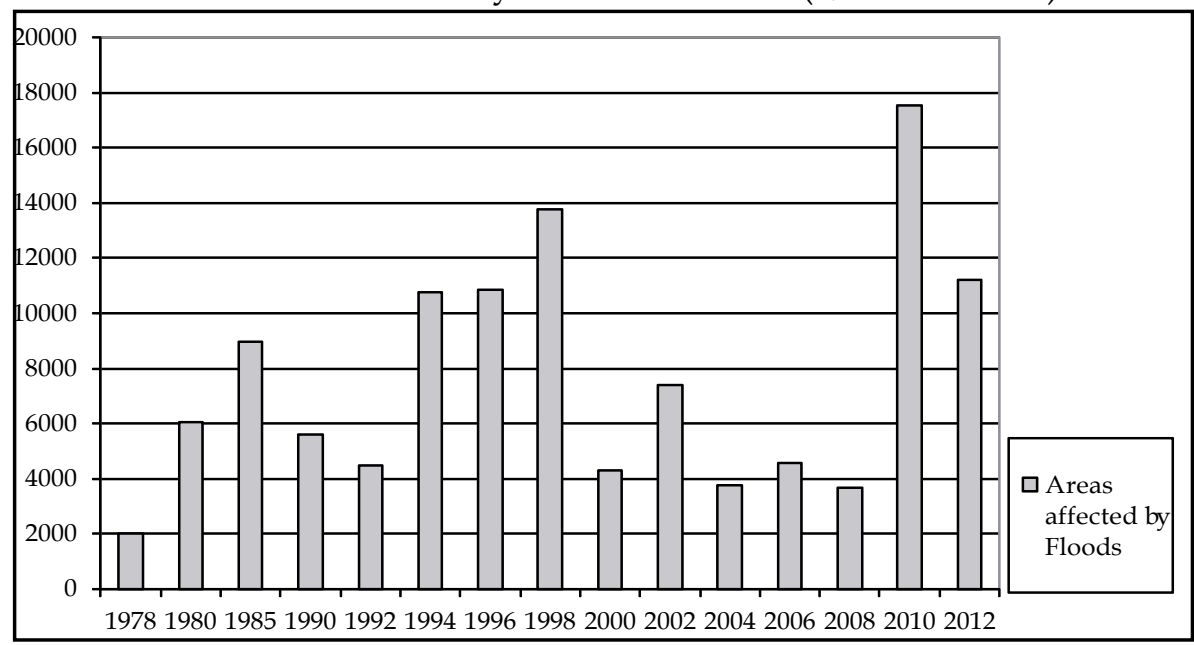

Source: China Statistical Yearbook (2009: 479)

2008, however, the numbers have surged, which could be explained by increased extreme weather in the context of climate change and local nonfeasance in maintaining water conservancy facilities.

With respect to preparedness measures, the Chinese government has not only mapped out national emergency response plans for major types of natural disasters, but also has built up a three-tiered manpower mobilization mechanism that includes professional teams, volunteers and community-based human resources to respond to disasters. In addition, the Chinese government has established special financial budgets for the response to and relief of general disasters and several central and local government departments, including civil affairs, water resources, agriculture and forestry, have established a system for stocking disaster relief materials. This system consists of ten central government stocks and local stocks in areas where disasters happen frequently (United Nations Economic and Social Council 2008: 14).

The PRC has frequently mobilized troops to combat disasters such as floods, earthquakes, snowstorms and forest fires. Now with 2.3 million soldiers, the People's Liberation Army (PLA) has been institutionalized as the country's most important rescue team in major disaster relief campaigns. According to the PRC Law on National Defence enacted in 1997, military personnel on active duty shall 'accomplish the tasks of dealing with emergencies and providing disaster relief'. ${ }^{8}$ During a rare snowstorm that affected much of southern and central China in early 2008, 306,000 PLA soldiers plus 1.07 million militia and army reservists were mobilized in the disaster relief effort. ${ }^{9}$ Within hours of 
the Sichuan earthquake in 2008, thousands of soldiers and police were being deployed, with military helicopters heading for the epicentre to help with rescue efforts. Within three days, tens of thousands of troops were racing to the region to pull people from the rubble.

China today is much better equipped technologically than before to deal with natural catastrophes, with improved high-tech systems for forecasting and monitoring disasters. Since the effectiveness of disaster management relies greatly on the utilization of related technology and information, the country has made a strenuous effort to improve its knowledge and technological capacity in all fields related to disaster mitigation. Relying on meteorological, oceanic and land resources, satellites as well as ordinary aeroplanes and unmanned planes, China has been using remote sensing and satellite positioning technology for surveillance tasks. Within two hours of the Sichuan earthquake, a map indicating basic information about the epicentre and major affected areas had been prepared by the National Disaster Reduction Centre, an information-sharing platform under the Ministry of Civil Affairs. In the following days, 120 maps and reports derived from satellite and aeroplane images were submitted by the Centre and its cooperative partners. Manned and unmanned aeroplanes equipped with remote sensors flew over the areas hit by the quake to collect field information with a view to more effectively deploying rescue and mitigation forces and relocating affected people (United Nations Economic and Social Council 2008: 6).

\section{Sichuan Earthquake: Emerging Challenges from Citizen Activism and Intra-elite Tensions}

Despite the effective rescue and reconstruction work in the aftermath of the Sichuan earthquake in 2008, growing civic activism and supervision facilitated by online media as well as intra-regime tensions emerged during the rescue and reconstruction process, which posed substantial challenges to China's disaster management systems.

First, the Party-state's non-participatory approach was questioned by the rising civic activism associated with the use of the Internet and burgeoning social media. This was unprecedented. For the first time, the Internet proved to be a crucial channel of information in China's disaster relief work. It served at least three important functions in the wake of the earthquake: information, expressionand civic mobilization (Yang 2008: 5). As a consequence of more than a decade of civil society 
development in China, citizens responded to the disaster just as quickly as the government, with the Internet being an uncensored channel of information and communication among civic forces. For citizens, the Internet was the most important channel of information during the earthquake, followed closely by television (Table 1). Internet-mobilized civic actions posed a threat to the overwhelming role played by the state in disaster management. Government-organized non-governmental organizations (GONGOs) like the Red Cross Society of China and China Charity Federation, which had monopolized the receipt of donations in disasters, faced competition from online fund-raising organized by major web sites and pure non-governmental organizations (NGOs) such as martial arts star Jet Li's One Foundation. In the first 24 hours after the quake, individual volunteers rushed to the quake-hit regions in Sichuan Province, driving their own vehicles and using their own rescue tools. Environmental and educational NGOs in Beijing initiated a 'Green Ribbon' campaign, in which their members and volunteers fanned out in the streets in fund-raising and blood drives.

TABLE 1: Main Channels of Information after the Sichuan Earthquake in $2008(n=523)$

\begin{tabular}{|l|c|}
\hline Information Channel & $\mathbf{\%}$ \\
\hline Internet & 36 \\
\hline Television & 34 \\
\hline Newspaper & 20 \\
\hline Cellular phone & 5 \\
\hline Radio & 4 \\
\hline Magazine & 1 \\
\hline
\end{tabular}

Source: Yang 2008: 4

Second, despite the government's strict control and restrictions over NGOs and the media, its management of natural disasters encountered increasing oversight and criticism from society. Such investigative actions initiated by individuals against disaster-related graft first focused on shoddy public buildings that had killed thousands of students during the quake. The non-repressive disaster management sector appeared to be repressive under the condition that civic activities posed a serious threat to the CCP's core interest in maintaining its legitimacy and positive image among the public. Civil right activists including Ai Weiwei, Tan Zuoren and dozens of volunteers participated in the investigation into the poor construction of the schools and posted the evidence they had collected on their online blogs. Their claims conflicted with the of- 
ficial stand that no students were killed by substandard school buildingsand subsequently both Tan and Ai were arrested. Nevertheless, public concern over corruption continued during the reconstruction period when more reports were released about the misuse and embezzlement of donation funds and materials. A Sichuan secondary school rebuilt in 2010 with $\mathrm{HK} \$ 2$ million in quake relief funds was later torn down to make way for a luxury housing development. ${ }^{10}$ With the quick spread of social media, the government has appeared more vulnerable when trying to fend off accusations supported by evidence.

Third, China's centralized way of handling the earthquake in 2008 revealed its weakness in coordination and cooperation among different institutional actors. Overloaded with excessive responsibilities in disaster management, the central government has to take care of almost all trivial details related to organizing donations, sending reports to the disaster zones, transporting aid materials and dispersing compensation funds. This increases the difficulty in coordinating work among various sectors and in implementing detailed instructions and policies; on many occasions this causes inefficiency and even corruption. Premier Wen Jiabao, head of the Earthquake Relief Headquarters of the State Council, had to bark orders to army generals over whom Wen had no power when he learned that rescuers from the People's Liberation Army had yet to reach Wenchuan, a city of 100,000 at the quake's epicentre. ${ }^{11}$ Local governments at various levels did not follow their superiors' instructions when allocating relief and recovery funds. Meanwhile, the central and local governments often have different perceptions of the importance of disaster management. Obsessed with high-speed economic growth, which has become a major indicator to measure the performance of administrative chiefs, local governments at various levels pay much more attention to glamorous industrial and urban projects instead of disaster preparation and relief projects. Due to insufficient funding from local budgets, some remote seismological observatories and disaster reduction facilities cannot be maintained. ${ }^{12}$ The earthquake in 2008and floods and mudslides in 2010 can be considered timely wake-up calls for the government on the need to pay more attention to the development of local disaster reduction infrastructure that has lagged behind the expansion of urban areas and urban population growth. 


\section{Reinstitutionalization after 2008}

Having drawn lessons from relief work in the 2008 Sichuan earthquake, the Chinese leadership reinstituted the holistic disaster management system by formulating the National Emergency Response Plan for Natural Disaster Relief, ${ }^{13}$ which gave detailed operating guidelines for the division of work among various institutional actors based on the severity of disasters. In addition to this new plan, applicable to relief actions for all kinds of natural disasters, thematic disaster response systems including ad hoc response plans targeting specific types of disasters were also regularized to improve administrative efficiency and avoid central-local and administrative-military inconsonance. Nevertheless, more pressing issues linked to rising citizen activism in disaster relief, online oversight and social media's role in information sharing were overlooked in the reinstitution process. To a large extent, the reform since 2008, with limited technical and administrative improvement, has reinforced the authoritarian regime's non-participatory style in disaster management, a trend contrary to the growing civic demand for more participation in public affairs amidst the new Internet and social media culture.

The Sichuan earthquake in 2008 catalyzed the enactment of the National Emergency Response Plan for Natural Disaster Relief in October 2011. Previously, the government's disaster response plan was only included as part of the National Master Plan for Responding to Public Emergencies, in which most of the guidelines were generalized for all public emergency events, not specifically designed for disaster management. For a long time China had no specific emergency response plan to deal with certain types of natural disasters, nor did China classify the disasters according to their severity, controllability or affected areas. In the new framework of the National Emergency Response Plan for Natural Disaster Relief, the Chinese government classified natural disasters into four response categories, based on the severity and controllability of disasters. ${ }^{14}$ Level I is for the most severe situation, where at least 200 people are killed (or over one million people need emergency aid in the disaster). The response is organized directly by the vice-premier-level director of the National Disaster Reduction Commission in the central government, together with the affected provincial and local governments. Level II is for very severe disasters with a death toll between 100 and 200, where the minister of civil affairs (also the deputy director of the National Disaster Reduction Commission) should organize and coordinate disaster relief work. Level III is for severe disasters with 
adeath toll between 50 and 100, where the vice-ministerial-level secretary-general of the National Disaster Reduction Commission should take charge of the coordination work. Level IV is for general disasters with a death toll below 50, where the Office of the National Disaster Reduction Commission should organize and coordinate relief work.

Through the classification of natural disasters based on severity, the central government has found it easier to figure out the amount of funds that should be allocated to different disasters as well as which level of government officials should play a pivotal role in disaster relief work. In addition, the National Emergency Response Plan for Natural Disaster Relief has reinforced the leading role of the government, especially the central government, in disaster relief work. The plan replaced the traditional principle of 'combination of central and regional system while giving priority to the regional system' (tiaokuaijiehe yikuaiweizhu) with the new norm of 'singular leadership at the central level' (tongyi lingdao) and 'government dominance in relief work' (zhengfu zhudao). After the Tax Sharing Reform in 1994, which greatly enhanced the fiscal capacity of local governments at various levels, regional governments have simultaneously increased their power in disaster relief work. At the same time, the reinstitution again consolidated the role of the central government in the fragmented disaster management system. Premier Wen's plight vis-à-vis the military in the 2008 earthquake should be averted under the new system where the PLA, as an institutional member of the National Disaster Reduction Commission, has to obey orders from the unitary leadership of the Commission.

Besides the National Emergency Response Plan for Natural Disaster Relief that is applicable to all kinds of natural disasters, ad hoc response plans have been put into place to handle specific types of disasters. These include the National Emergency Response Plan for Flood and Drought Disasters, National Emergency Response Plan for Earthquake Disasters, National Emergency Response Plan for Geological Disasters and National Emergency Response Plan for Very Severe and Most Severe Forest Fire Disasters. Horizontally, the central government has set up various interagency mechanisms to ensure the clear-cut division of work among involved ministries and departments. For routine jobs on disaster relief, the Ministry of Civil Affairs plays the pivotal role in coordinating the work of different sectors. In catastrophic disasters like the 2008 Sichuan earthquake or the 2010 Yangtze River floods, ad hoc interagency panels such as the Earthquake Relief Headquarters and the State Flood Control and Drought Relief Headquarters command the disaster relief campaigns. 
According to relevant legal documents, all the involved departments and sectors have been assigned well-defined jobs in the colossal bureaucratic system on disaster management to avoid administrative chaos, with punishment in place for the breach of duty.

The Chinese government set up the Earthquake Relief Headquarters of the State Council (guowuyuan kangzhenjiuzai zongzhihuibu) in response to the 2008 Sichuan earthquake. The deadly 8.0-magnitude quake hit southwest Sichuan Province on 12 May. On 18 May 2008, the State Council publicized the details of the Earthquake Relief Headquarters, which was divided into nine interagency work groups to coordinate the work among various sectors. ${ }^{15} \mathrm{~A}$ ministry or department was appointed to play a pivotal role in each group: the General Staff Department of the Chinese army coordinated the emergency response group, the Ministry of Civil Affairs coordinated the disaster relief group, the China Earthquake Administration coordinated the earthquake monitoring group and the Ministry of Health was the coordinator in the public health and anti-epidemic group.

The Earthquake Relief Headquarters of the State Council was specifically set up to deal with the 2008 Sichuan earthquake, but such ad hoc mechanisms continue to exist long after the occurrence of the quake. This is mainly because the reconstruction and recovery process takes a long time in the province and the central government has realized the importance of maintaining the mechanism to respond to severe earthquakes that may strike China again in the future. When Yushu, in northwestern China's Qinghai Province, was hit by a devastating magnitude 6.9 earthquake in April 2010, the Earthquake Relief Headquarters of the State Council immediately organized emergency aid and disaster relief work at the national level.

Both the State Flood Control and Drought Relief Headquarters and the Earthquake Relief Headquarters are ad hoc interagency mechanisms under the State Council, but there is a structural distinction between them. The Earthquake Relief Headquarters is a multi-layer organization comprised of various work groups, each of which is headed by a certain ministry or department, while the State Flood Control and Drought Relief Headquarters has no such subgroups and is simply a two-layer organization in which the Ministry of Water Resources plays a pivotal role. 


\section{Second Sichuan Earthquake in a Social Media Era: The Limits to the Reinstitution}

China's reinstitution of the disaster management system since 2008 proved to be effective in mobilizing the top-down bureaucracy to cope with the second Sichuan earthquake, in Lushan County, Ya'an in April 2013. The political authority of the newly anointed premier Li Keqiang, as well as his State Council colleagues sitting on the National Disaster Reduction Commission, was undeniably respected by both the military and local governments. Technically speaking, the leadership was more efficient than five years earlier in coordinating various intra-bureaucracy players to achieve a better division of work, relying more on the institutionalized procedures set by the National Emergency Response Plan for Natural Disaster Relief. Based on the rough death toll figure (less than 100) provided by the local government, the Ministry of Civil Affairs originally only launched a level III response for rescue and relief work, which fit strictly in the categorization of disasters written into the $\mathrm{Na}$ tional Emergency Response Plan for Natural Disaster Relief. The central authority later raised the response level to the highest level (level I) only when the death toll rose to above 200, which also triggered the involvement of higher-ranking officials. The government-dominated relief work was logistically efficient, since helicopters reached the disaster site within hours, while workers dynamited their way through roads blocked by landslides, making the quake zone accessible by road eight hours later, a marked improvement from more than three days taken during the 2008 quake. Infrastructure was restored more expediently, with electricity and communications networks up and running the next day.

On the other hand, the reinforcement of the authoritarian regime's non-participatory style in disaster management since 2008 further contradicted the growing civic demand for more participation in public affairs amidst the new social media culture. In the self-reinforced, statecentric disaster management system, the reform failed to address the urgent civic demand for substantial participation and supervision, with the increasingly salient influence of the Internet and social media being overlooked by the institutional designers. Such neglect subsequently had an unanticipated negative impact on the credibility of the government-dominated disaster management system in the second Sichuan earthquake, in 2013.

The first day after the earthquake, the government-organized Red Cross Society of China encountered an unprecedented credibility crisis 
in People's Republic of China's history when it received a mere 140,000 yuan (US\$22,700) in donations, compared to 10 million yuan taken in by Jet Li's One Foundation. ${ }^{16}$ The public image of China's Red Cross had been severely damaged in 2011 by a scandal revealed online where a woman known as Guo Meimei, who may have traded on a presumed connection through a company called Red Cross Commerce, bragged of her luxurious lifestyle, posting photos of expensive cars and luxury accessories on Sina Weibo, China's most popular Twitter-like microb$\log$ service. Meanwhile, it was widely circulated on social media, with evidence provided by reporters and whistle-blowers, that following the 2008 Sichuan earthquake, billions of yuan in donations managed by China's Red Cross had gone missing.

The substantial loss of donations absorbed by government-linked organizations between the two Sichuan earthquakes reflects the government's inability to maintain its credibility, which has been severely challenged in the social media era. Rising civic demand for more participation in the rescue and relief was still suppressed by the regime in the 2013 Sichuan earthquake, although ordinary people had been engaging in a broad range of political action and finding a new sense of self, community and empowerment in the those five years. The reinstitution within the authoritarian regime has improved the hardware aspects of disaster management, but ignored the most salient civil society dynamics driven by cyberspace activism and civic consciousness that may pose lethal challenges to the authoritarian regime itself.

\section{Conclusion}

In the study of institutionalization in authoritarian regimes, non-repressive institutional pillars such as the disaster management system in a non-democratic government are often neglected. Through the research on China's two rounds of reinstitutionalization in the reform period in the realm of natural disaster management, the article attempts to make contributions to new institutionalist studies of authoritarianism to help explain the CCP's 'authoritarian resilience'. Based on analysis of the evolution of China's thematic disaster response plans and disaster management mechanisms in the reform period, the article has discussed different fundamental challenges the authoritarian institutional designers needed to address before and after the 2008 Sichuan earthquake in disaster managementand to what extent the institutionalization or reinstitutionalization has been effective in addressing these challenges. 
In the first three decades of the reform era, the CCP gradually normalized the bureaucratic system in charge of natural disaster management once disrupted by the anarchical Cultural Revolution. The Party-state's normalization and institutionalization of the bureaucratic system overseeing natural disaster management have profound political implications in coordinating intractable central-local relations and improving the regime's international image and legitimacy. The system now has a clear-cut division of responsibilities among various departments, recognizes well-established international norms such as openness to foreign aidand prioritizes pre-disaster mitigation and preparedness as well as equipment of high-tech surveillance and logistical systems. As a result of the re-establishment of the disaster management bureaucracy the government has managed to keep the casualties caused by natural disasters relatively low. Targeting problems revealed in the 2008 Sichuan earthquake, the Chinese leadership reinstituted the holistic disaster management system by formulating the National Emergency Response Plan for Natural Disaster Relief that detailed the division of responsibilities among various institutional actors based on the severity of disasters. Nevertheless, more pressing issues linked to rising citizen activism in disaster relief, online oversight and social media's role in information sharing have been overlooked in the reinstitution process. The resilient Party-state system has ostensibly showed leniency towards growing civic participation in disaster management and recovery, giving societal forces more room to manoeuvre in the new institutions, but whenever civic activities posed a threat to the CCP's core interest in maintaining its legitimacy and image among the public, the nonrepressive disaster management sector appeared to be repressive and intolerant. To a great extent, the reform since 2008, with technical and administrative improvement, has reinforced the authoritarian regime's non-participatory style in disaster management, a trend contrary to the growing civic demand for more participation in public affairs amidst the new Internet and social media culture.

Dr. Chen Gang is Research Fellow at the East Asian Institute (EAI), National University of Singapore. His research interests include China's domestic politics and environmental governance. Email: eaicg@nus.edu.sg 


\section{NOTES}

1 The author would like to thank the three anonymous reviewers for their insightful comments but assumes the sole responsibility for any possible errors in the paper.

2 The term 'authoritarian resilience' was first used by Nathan (2003) to describe the CCP regime's resilience after the Tiananmen crisis in 1989, contrary to popular belief among many China specialists and democracy theorists that the CCP rule would soon fall to democratization's 'third wave'. To explain such resilience, Nathan focused on four aspects of the CCP regime's institutionalization: 1) the increasingly normbound nature of its succession politics; 2 ) the increase in meritocratic as opposed to factional considerations in the promotion of political elites; 3 ) the differentiation and functional specialization of institutions within the regime; and 4) the establishment of institutions for political participation and appeal that strengthen the CCP's legitimacy among the public. Through the study of institutional and capacity building in the area of disaster management, this article aims to enhance understanding of the abovementioned third and fourth aspects with discussion on how the authoritarian regime has been capable of dealing with natural disasters and where the institutional constraints exist.

3 The focus of the research has been narrowed down to natural disaster management, instead of disaster management in a broader sense, which includes all types of disasters such as industrial accidents, pollution incidents and terrorist attacks.

4 State Council General Office, 1998, 'Circular on the departments established inside the Ministry of Civil Affairs and related established posts' (guowuyuan bangongting guanyu yinfa minzhengbu zhinengpeizhi neishejigou he renyuanbianzhi guiding de tongzhi). Available at: http:/ /law.lawtime.cn/d466727471821.html.

5 Asian Disaster Reduction Center (ADRC), 2010, 'Information on Disaster Risk Reduction of the Member Countries-China'. Available at: http:/ / www.adrc.asia/nationinformation.php? NationCode=156\&Lang=en\&NationNum=22 (accessed 1 November 2010).

6 Ministry of Civil Affairs, 2010, 'Function of the Disaster-Relief Bureau of the PRC Ministry of Civil Affairs', http:/ /jzs.mca.gov.cn/article/jgzn/ (accessed 2 November 2010).

7 The New York Times, 13 September 2005, 'China's State Secrets Agency Will Guard One Less: Death Tolls'. Available at: http:/ / www.nytimes.com/2005/09/13/international/asia/13china.html (accessed 2 January 2014).

8 PRC Law on National Defence 1997: Article 58.

9 Xinhua News, 3 February 2008, '306,000 troops mobilized to combat snow disasters'.

10 The Independent, 24 April 2013, 'Sichuan earthquake: Hong Kong urges aid veto over corruption fears'. Available at: http://www.independent.co.uk/news/world/ asia/sichuan-earthquake-hong-kong-urges-aid-veto-over-corruption-fears-8586856. html.

11 The New York Times, 21 May 2008, 'In Quake, Apotheosis of Premier 'Grandpa". Available at: http://www.nytimes.com/2008/05/21/world/asia/21wen. html? pagewanted=all\&_r=0 (accessed 5 January 2014).

12 Jinan Times, 21 April 2013, 'Criticism over little spending on seismological forecast' (dizhen yuce jingfei pianshao zaogoubing). Available at: http:// news.ifeng.com/mainland/special/lushandizhen/content-3/detail_2013_04/21/24456920_0.shtml?_ from_ralated (accessed 3 January 2014).

13 State Council, 2011, 'National Emergency Response Plan for Natural Disaster Relief' (guojia ziran zaihai jiuzhu yingji yu'an). Available at: http://www.gov.cn/yjgl/201111/01/content_1983551.htm.

14 State Council, 2011, 'National Emergency Response Plan for Natural Disaster Relief' 
(guojia ziran zaihai jiuzhu yingji yu'an). Available at: http://www.gov.cn/yjgl/201111/01/content_1983551.htm.

15 State Council, 18 May 2008, 'Circular on the Component Workgroups of the State Council Earthquake Relief Headquarters' (guanyu guowuyuan kangzhenjiuzai zongzhihuibu gongzuozu zucheng de tongzhi).

16 The Wall Street Journal, 30 April 2013, 'China's Red Cross Tries to Rebuild After SelfInflicted Disaster'. Available at: http:/ / blogs.wsj.com/chinarealtime/2013/04/30/ chinas-red-cross-tries-to-rebuild-after-self-inflicted-disaster (accessed 7 January 2014).

\section{REFERENCES}

Aoki, Masahiko 2001. Toward a Comparative Institutional Analysis. Cambridge: The MIT Press.

Brødsgaard, Kjeld Erik 2002. 'Institutional Reform and the Bianzhi System in China'. The China Quarterly 170: 361-386.

Chen, Gang 2012. 'China's management of natural disasters: organizations and norms'. In China's Crisis Management, edited by Jae Ho Chung, pp. 130-148. London: Routledge.

China Statistical Yearbook. 2009, 2011, 2013. Beijing: China Statistics Press.

Chung, Jae-ho 1995. 'Beijing Confronting the Provinces: The 1994 Tax-sharing System and Its Implications for Central-Local Relations in China'. China Information 9 (2/3): $1-23$.

Deng, Tuo 1937. China's History of Disaster Relief (Zhongguo jiuhuang shi). Shanghai: The Commercial Press.

Dong, Wei. South-Song-Dynasty (1127-1279 AD), Book on Disaster Relief and Lifesaving (Jiuhuang huomin shu).

Gong, Shuduo 1996. Chinese Social History-ROC Volume (Zhongguo Shehui Tongshi-Mingguo Juan). Taiyuan: Shanxi Education Press.

Greif, Avner 2006. Institutions and the Path to the Modern Economy: Lessons from Medieval Trade. Cambridge: Cambridge University Press.

Hall, Peter and David Soskice (eds.) 2001. Varieties of Capitalism: The Institutional Foundations of Comparative Advantage. Oxford: Oxford University Press.

Heilmann, Sebastian and Elizabeth J. Perry (eds.) 2011. Mao's Invisible Hand: The Political Foundations of Adaptive Governance in China. Cambridge, MA: Harvard University Press.

Huntington, Samuel 1968. Political Order in Changing Societies. New Haven: Yale University Press.

Krasner, Stephen D. (ed.) 1983. International Regimes. Ithaca: Cornell University Press.

Li, Cheng 2009. 'Intra-Party Democracy in China: Should We Take It Seriously?' China Leadership Monitor 30.

Lim, Wee-Kiat 2011. 'Understanding risk governance: Introducing Sociological Neoinstitutionalism and Foucauldian Governmentality for Further Theorizing'. International Journal of Disaster Risk Science 2: 11-20.

Lin, Shuanglin 2000. 'The Decline of China's Budgetary Revenue: Reasons and Consequences'. Contemporary Economic Policy 18 (4): 477-490.

Loo, Becky P. Y.and Sin Yin Chow 2006. 'China's 1994 Tax-Sharing Reforms: One System, Differential Impact'. Asian Survey 46 (2): 215-237.

Meng, Shaohua 1999. China's History of Disasters and Famines (Zhongguo Zaihuangshiji). Beijing: Zhongguo Shehui Chubanshe. 
Nathanandrew 2003. 'China's Resilient Authoritarianism'. Journal of Democracy 14 (1): 6-17.

North, Douglass C. 1990. Institutions, Institutional Change and Economic Performance. Cambridge: Cambridge University Press.

Pieke, Frank 2009. The Good Communist: Elite Training and State Building in Today's China. Cambridge: Cambridge University Press.

Schedlerandreas 2009. 'The New Institutionalism in the Study of Authoritarian Regimes'. Paper for American Political Science Association 2009 Annual Meeting.

Shambaugh, David 2008. 'Training China's Political Elite: The Party School System'. The China Quarterly 197: 827-844.

Shambaugh, David 2012. 'International Perspectives on the Communist Party of China'. China: An International Journal 10 (2): 8-22.

Sun, Shaocheng 2004. Research on China's Disaster Relief Institutions (Zhongguo Jiuzai Zhidu Yanjiu). Beijing: The Commercial Press.

Tan, Ngoh Tiong, Yunong Huang and Lihrong Wang 2011. 'Disaster Management in China and Taiwan: Models, Policiesand Programs for Social Recovery'. Journal of Global Social Work Practice (electronic journal) 4(1).

United Nations Economic and Social Council. 2008. 'Implementation of the Hyogo Framework for Action in Asia and the Pacific: Case Study: The National Disaster Management System of China and its Response to the Wenchuan Earthquake'. Available at: http://www.unescap.org/idd/events/cdrr-2009/CDR_2E.pdf.

Wang, Bin and Huang Lei 2013. 'Social Management in China in the 21st Century: Trouble and Breakthrough Based on the Different Management Subject'. Public Administration Research 2 (2): 73-79.

Wang, Zhengxu and Ern Ser Tan 2013. 'The Conundrum of Authoritarian Resiliency:

Hybrid and Nondemocratic Regimes in East Asia'. Taiwan Journal of Democracy 9 (1): 199-219.

Winckler, Edwin 1984. 'Institutionalization and Participation on Taiwan: From Hard to Soft Authoritarianism?' The China Quarterly 99: 481-499.

Yang, Guobin 2008. 'Sichuan Earthquakes and Relief Efforts: The Power of the Internet'. EAI (East Asian Institute) Background Brief, Singapore, No. 389.

Yang, Guobin 2009. The Power of the Internet in China. New York: Columbia University Press.

Yi, Lixin, Ge Lingling, Zhao Dong, Zhou Junxue and Gao Zhanwu 2012. 'An analysis on disasters management system in China'. Natural Hazards 60: 295-309.

Zheng, Yongnian 2007. De Facto Federalism in China: Reforms and Dynamics of Central-Local Relations. Singapore: World Scientific.

Zheng, Yongnian 2012. 'Where Does the Chinese Communist Party Go From Here? Challenges and Opportunities'. China: An International Journal 10 (2): 84-101. 